\title{
43.Türkçe eğitimi alanındaki kadın akademisyenlerin akademik çalışmalarının bibliyometrik analizi
}

\author{
Songül KARAKUZU ${ }^{1}$ \\ Merve ARAS2 \\ Özlem GEDİKLİ3
}

\begin{abstract}
APA: Karakuzu, S.; Aras M.; Gedikli, Ö. (2021). Türkçe eğitimi alanındaki kadın akademisyenlerin akademik çalışmalarının bibliyometrik analizi. RumeliDE Dil ve Edebiyat Araştırmaları Dergisi, (22), 691-705. DOI: 10.29000/rumelide.897125.
\end{abstract}

\section{$\ddot{\mathbf{O} z}$}

Kadınlar, hemen her çalışma alanında olduğu gibi akademide de önemli bir niceliğe ve niteliğe sahiptir. Öğretmen ve akademisyen yetiştirme amacının yanında bilime katkı sağlayan eğitim fakültelerinde çalışan kadın akademisyenler, toplam akademisyen sayısının \%49,4’ünü oluşturmaktadır. Eğitim fakültelerinin temel alanlarından Türkçe Eğitimi Ana Bilim Dalı’nda çalışan kadın akademisyenlerin sayısıysa 547 akademisyen arasında 247’ye ulaşmıştır. Çalışmada, Türkçe eğitimi alanındaki kadın akademisyenlerin ulusal ve uluslararası bilime katkılarının ortaya konulması amaçlanmıştır. Türkçe eğitimi alanındaki kadın akademisyenlerin alana katkıları; çeşitli ölçütler bağlamında ele alınmıştır. Bu bağlamda kadın akademisyenlerin sayısına, unvanlarına, çalıştıkları kurum türlerine, lisansüstü tez danışmanlıklarına, akademik çalışmalarının türlerine göre dağılımları ile makalelerin tarandığı dizinler belirlenmiştir. Ardından kadın akademisyenlere dair elde edilen veriler, bibliyometrik analiz yöntemiyle incelenmiştir. Çalışma sonucunda Türkçe eğitimi alanında çalışan kadın akademisyenlerin sayıları, unvan ve çalıştıkları kurumlara göre dağılımları tablolaştırılmıştır. Ayrıca alandaki bilimsel katkılarının önemi bildiri, makale ve kitap yayımları ile lisansüstü tez danışmanlıkları aracılığıyla ortaya konmaya çalışılmıştır. Çalışma sonucunda kadın ve erkek akademisyenler arasında niceliksel olarak büyük farklılıkların bulunmadığı görülmüştür. Bunun yanında öğretim görevlisi kadın akademisyenlerin ( $\mathrm{f}=79$ ) erkek öğretim görevlilerinden ( $\mathrm{f}=71$ ), araştırma görevlisi kadın akademisyenlerin ( $\mathrm{f}=61$ ) de erkek meslektaşlarından $(\mathrm{f}=60)$ sayıca fazla olduğu tespit edilmiştir. Diğer akademik unvanlardaki eşitsizliğin sebebi ise toplum içinde kadına yüklenen rollerin akademik ilerleyişi olumsuz etkilemesi olarak değerlendirilmiştir. Tüm bunlara rağmen kadının akademide de önemli bir yere sahip olduğu yapılan çalışmadan çıkarılan en önemli sonuçtur.

Anahtar kelimeler: Kadın akademisyen, Türkçe eğitimi alanı, bibliyometri

\footnotetext{
1 YL. Öğrencisi, Tokat Gaziosmanpaşa Üniversitesi, Eğitim Bilimleri Enstitüsü, Türkçe Eğitimi ABD (Tokat, Türkiye) songul.karakuzu0220@gop.edu.tr, ORCID: 0000-0002-5246-5083 [Araștırma makalesi, Makale kayıt tarihi: 08.12.2020-kabul tarihi: 20.03.2021; DOI: 10.29000/rumelide.897125]

$2 \quad$ YL. Öğrencisi, Tokat Gaziosmanpaşa Üniversitesi, Eğitim Bilimleri Enstitüsü, Türkçe Eğitimi ABD (Tokat, Türkiye) merve.aras5819@gop.edu.tr, ORCID ID: 0000-0003-0821-3898

3 Arş. Gör., Tokat Gaziosmanpaşa Üniversitesi, Eğitim Bilimleri Enstitüsü, Türkçe Eğitimi ABD (Tokat, Türkiye) ozlem.gedikli@gop.edur.tr, ORCID ID: oooo-0002-2270-7280

Adres $\mid$ Address

RumeliDE Dil ve Edebiyat Araşttrmalar Dergisi $\quad$ RumeliDE Journal of Language and Literature Studies Osmanağa Mahallesi, Mürver Çiçeği Sokak, No:14/8 Osmanağa Mahallesi, Mürver Çiçeği Sokak, No:14/8

Kadıköy - İSTANBUL / TÜRKIYE 34714 Kadıköy - ISTANBUL / TURKEY 34714 e-posta: tel: +90 $5057958124,+902167730616$

e-mail: editor@rumelide.com

phone: +90 505 7958124, +90 2167730616
} 


\title{
Bibliometric analysis of academic studies of women academicians in the field of Turkish language education
}

\begin{abstract}
Women have an important quantity and quality in academia, as in almost every field of study. In addition to the aim of training teachers and academicians, women academicians working in education faculties that contribute to science constitute $49.4 \%$ of the total number of academicians. The number of female academicians working in Turkish Language Education Department, one of the main fields of education faculties, reached 247 among 547 academicians. In the study, it is aimed to reveal the contributions of female academicians in the field of Turkish language education to national and international science. For this purpose, the data obtained about women academicians were examined by bibliometric analysis. The contributions of women academics in the field of Turkish language education are discussed in the context of various criteria. In this context, the number of women academics, their titles, the types of institutions they work in, graduate thesis consultations, the types of academic work according to the distributions and the directories in which the articles are scanned were determined. Then the data obtained about women academicians were examined by bibliometric analysis. As a result of the study, the distribution of female academicians working in the field of Turkish language education according to the number, title and institutions was tabulated. In addition, the importance of scientific contributions in the field was tried to be revealed through papers, articles and book publications and graduate thesis consultancy. As a result of the study, it was observed that there were no major quantitative differences between men and women academicians. In addition, it was determined that there are more women lecturers $(f=79)$ than men lecturers $(f=71)$ and women research assistants $(f=61)$ than men research assistants $(f=60)$. The reason of the inequality in other academic titles was evaluated as the negative effects of the roles assigned to women in the society on academic progress. Despite all this, it is the most important conclusion from the study that women have an important place in the academy.
\end{abstract}

Keywords: Women academic, Turkish language education field, bibliometry

\section{Giriş}

Dünyada olduğu gibi Türkiye'de de kadınların işgücüne katılım oranları ekonomik, sosyal ve kültürel açıdan büyük bir önem taşımaktadır. Türkiye İstatistik Kurumu'nun (TUİK) 2019 verilerine göre Türkiye nüfusunun \%49,8'ini oluşturan kadınlar; işletme, idare, hukuk, teknoloji, mühendislik, inşaat, imalat ve yapı, sağllk ve refah gibi alanların yanında eğitim alanında da kendilerini kanıtlamaktadırlar. Kadınlar; akademisyen, öğretmen ve yönetici gibi farklı görevlerde çalışarak eğitime katkı sunan bir kesimdir.

Kadınlara toplum tarafından yüklenen bazı durumlarla cinsiyet eşitsizliğinin iş hayatına yansıması sonucunda, akademisyen kadınların iş ve aile hayatının olumsuz etkilendiğini çalışmalarında ortaya koyan Başarır ve Sarı (2015), kadınların geleneksel ev işleri, çocuk bakımı gibi olağan görevleri yanında ders anlatma, bilimsel araştırma yapma, kitap ve makale yazma, kongre-konferans vb. etkinliklere katılma gibi mesleki sorumluluklarının olmasına dikkat çekmektedir. Bununla birlikte akademideki kadınların yükseköğrenime giriş ve kariyerde ilerleme durumlarını araştıran Adak'ın (2018) çalışması, Türkiye'de kadınların özellikle dil ve edebiyat, sosyal bilimler ve eğitimle ilgili

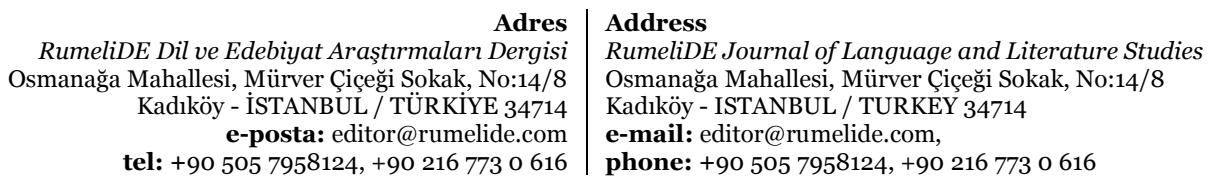


alanlarda uzmanlaşmayı tercih ederken erkeklerin fen, matematik ve mühendislikle ilgili alanlara yönelmesi yatay bir ayrışmanın olduğunu ortaya koymaktadır. Kim’e (Akt., Adak, 2018) göre dünyada kadın-erkek akademisyen oranlarının birbirine yaklaşması araştırmacıları alanlardaki cinsiyet durumlarını incelemeye yöneltmiştir. Yükseköğretim Bilgi Yönetim Sisteminin 4 Aralık 2020 tarihli verilerine bakıldığında bu konuda Türkiye'de iyileşen bir durum söz konusudur. Toplamda 175.260 akademisyen içinde 79.254 sayısına ulaşan kadın akademisyenlerin \%45,2'lik bir dilime sahip oldukları görülmektedir. Eğitim fakültelerine bakıldığındaysa bu sayının toplam 9.420 akademisyen içinde 4.661 olduğu görülmektedir. Bu veriler ışığında, kadın akademisyenlerin eğitim fakültelerinde \%49,4 ile akademik camianın genelinden daha büyük bir yere sahip olduğu görülmektedir.

Türkçe eğitimi alanında görev yapan kadın akademisyenleri odak alan bu çalışmada, eğitim fakültelerinin akademi içindeki yeri ve geçmişine de bakmak gerekir. Yükseköğretim içinde büyük bir paya ve yere sahip olan eğitim fakültelerinin geçmişi Cumhuriyet Dönemi’ne dayanmaktadır. Cumhuriyetin ilk yıllarında temeli atılan eğitim fakültelerinde sinırlı sayıda bölüm yer alır. Ortaokullara öğretmen yetiştirme amacıyla 1926-1927 eğitim öğretim yılında Konya'da açılan Orta Muallim Mektebi ve Terbiye Enstitüsündeki ilk bölümün Türkçe Öğretmenliği olması, ana dili eğitiminin yeni kurulan bir devlet için büyük bir öneme sahip olmasıyla açılanabilir. Zaman içerisinde sayısı artan Eğitim Enstitülerinde Türkçe Öğretmenliği temel bölüm olarak yerini almaya devam ederken 1982'de eğitim fakülteleri çatısı altında toplanan öğretmen yetiştirme kurumlarında, Türkçe Öğretmenliğine verilen önemin azaldığı görülür. Sadece liselere eğitim verme hedefi güden kurumlardan mezun olan öğretmen adaylarına ortaokula da ders verme hakkı tanınması yedi yıl boyunca devam eder. Bu sebeple zaman içinde ortaokul kademesine özgü ana dili öğretmeni yetiştirme ihtiyacı doğar. Bu süreçte bugünkü adıyla Türkçe Eğitimi Ana Bilim Dalı, 1989 yılında Türk Dili ve Edebiyatı Eğitimi Bölümü bünyesinde alanda akademisyen yetiştirmek amacıyla Türkçenin Eğitimi Öğretimi Ana Bilim Dalı olarak kurulur, 1992 yılından itibaren ise Türkçe Öğretmenliği Ana Bilim Dalı olarak adlandırılır (Güzel, 2010). Türkçe Öğretmenliği Bölümü, 2016-2017 akademik yılından itibaren adı Türkçe ve Sosyal Bilimler Eğitimi şeklinde değiştirilen bölüm altında anabilim dalına dönüştürülür. Otuz ylllık bir geçmişe sahip olan bu alanda günümüzde 300 erkek ve 247 kadın olmak üzere toplam 547 akademisyen görev yapmaktadır. Kadın ve erkek akademisyenler arasındaki nicelik açısından yakalanmaya çalışılan bu denge, kadın akademisyenlere dair birçok araştırmayı beraberinde getirmiştir.

Kadın akademisyenlerle ilgili çalışmalar incelendiğinde ulusal ve uluslararası alan yazında çok sayıda araştırma bulunduğu görülmektedir. Bu araştırmaların toplumsal cinsiyet rolleri bağlamında kadın akademisyenlerin üniversitelerde karşılaştıkları sorunlarını ve kadın akademisyen olmanın zorluklarını (Ercan Demirel ve Erdirençelebi, 2019; Tepe, 2018; Sart, Sezgin ve Demir, 2018; Yıldız, 2018; Suğur ve Cangöz, 2016; Özkanlı, 2010; Adak Özçelik ve Cömertler, 2005; Altınoluk Düztaş, 2018; Demir, 2018; Yenilmez, 2016; Ünnü Ayyldız, Baybars ve Kesken, 2014; Taylor Machado ve Özkanl, 2013; Dikmen ve Maden, 2012; Bakioğlu ve Ülker, 2018; Şentürk, 2012; Çakır ve Arslan, 2018; Yılmaz ve Özdemir, 2012; Öztürk, 2017), kadın akademisyenlerin iş-yaşam dengesini nasıl sağladıklarını (Bayramoğlu, 2018), ülkemizdeki kadın akademisyenlerin katkı sağladığı alanlara göre dağılımını (Özkanlı, 2007), kadın akademisyenlerin akademide kadın olarak yer almaya yönelik algılarını (Başarır ve Sarı, 2015; Yalçın ve Demirekin, 2013; Ehtiyar, Solmaz ve Üst Can, 2019), bazı akademik alanlardaki ilk kadın akademisyenleri (Küçükaslan, Başağaç ve Ünsal, 2017), Türkiye'deki bazı akademik alanlardaki cinsiyet temelli farklılaşmalarını (Öztan ve Doğan, 2015; Gönenç, Akgün, Özvarış ve Tunç, 2013; Çiçekli, 2019; Şentürk, 2016), bir akademik alandaki kadın akademisyenlerin eril diline ve erilleşmeye yönelik bakış açılarını (Özdemirkıran ve Öner, 2017) inceleyen araştırmalar

Adres $\mid$ Address

RumeliDE Dil ve Edebiyat Araştırmalar Dergisi $\quad$ RumeliDE Journal of Language and Literature Studies Osmanağa Mahallesi, Mürver Çiçeği Sokak, No:14/8 Osmanağa Mahallesi, Mürver Çiçeği Sokak, No:14/8 Kadıköy - İSTANBUL / TÜRKIYE 34714 Kadıköy - ISTANBUL / TURKEY 34714 e-posta: editor@rumelide.com e-mail: editor@rumelide.com,

tel: +90 505 7958124, +90 2167730616 phone: +90 505 7958124, +90 2167730616 
olduğu görülmektedir. Alan yazına bakıldığında herhangi bir akademik alanda bibliyometrik açıdan kadın akademisyenleri inceleyen sadece bir çalışma olduğu görülmektedir (Güçlü Nergiz, 2019).

Yükseköğretimde bir akademisyen olarak kadının bilimsel üretkenliğine dikkat çekmek amacıyla yapılan bu çalışmada, eğitim fakültelerinin ana alanlarından biri olan Türkçe eğitimi alanındaki kadın akademisyenlerin ulusal ve uluslararası bilime alan yazında yaptıkları katkılar belirli ölçütler nezdinde (unvanlarına, yayın türlerine, çalıştıkları kurum türlerine göre dağılımı; makalelerinin tarandığı dizinler, doktora ve yüksek lisans tezi yönetme durumları) bibliyometrik analiz yoluyla irdelenecektir. Bibliyometrik analiz tekniğinin seçilme sebebi Altaş’a (2017:105) göre, bu teknikle belirli bir alanda bir dönemde ve belirli bir bölgede kişiler ya da kurumlar tarafından üretilmiş yayınların ve bu yayınlar arasındaki ilişkilerin sayısal olarak analizinin yapılmasıdır.

Bibliyometrik çalışmalara, Türkçe eğitimi alanı dahil olmak üzere farklı konularda da rastlanmaktadır. Eleştirel düşünme üzerine yazılan 165 lisanüstü tezini; üniversitelerine, enstitülerine, ana bilim dallarına, bilim dallarına, yıllarına, program türüne, yöntemine ve konularına göre inceleyen Batur ve Özcan (2020), eleştirel düşünme hakkındaki tezlerin resmini çizmiştir. Türkçe Eğitimi alana dair yapılan bibliyometri çalışmalar incelendiğinde ise Karagöz ve Şeref'in (2019a) okuma alanındaki araştırmalara dair bibliyometrik bir çalışma ortaya koyduğu görülmektedir. Bunun yanında Karagöz ve Şeref (2019b), Türk milletinin en önemli tarihî şahsiyetlerinden biri olan Yunus Emre'yle ilgili yapılan araştırmaların sayısı, yayın dili, yayın türü, aktif araştırma yapılan ülkeler, anahtar kelimeler gibi değişkenler üzerinden de başka bir bibliyometrik çalışma gerçekleştirmiştir. Bu örnek çalışmalardan da yola çıkılarak kadın akademisyenlerin bilim dünyasındaki bütüncül resmine çekebilmek için bibliyometrik analiz yöntemi tercih edilmiştir.

Türkçe eğitimi alanındaki kadın akademisyenleri bibliyometrik göstergeler açısından inceleyen bu çalışma, alandaki kadın akademisyenlerin bilimsel varlığını ortaya koyan ilk çalışma olması sebebiyle önemlidir. Bunun yanında araştırmanın Türkçe eğitimi alanındaki kadın akademisyenlerin gelecekteki durumuna dair fikir vereceği düşünülmektedir.

\section{Araştırmanın amacı}

$\mathrm{Bu}$ çalışmanın amacı, Türkçe eğitimi alanındaki kadın akademisyenlerin belli ölçütler açısından incelenerek genel bir görünümünün sunulmasıdır. Bu amaç doğrultusunda aşağıdaki sorulara cevap aranmıştır:

1. Türkçe eğitimi alanında kadın akademisyenlerin sayısı nedir?

2. Türkçe eğitimi alanında kadın akademisyenlerin unvanlarına göre dağılımı nasıldır?

3. Türkçe eğitimi alanında kadın akademisyenlerin çalıştıkları kurum türlerine göre dağılımı nasıldır?

4. Türkçe eğitimi alanında kadın akademisyenlerin yüksek lisans ve doktora tez danışmanlıklarına göre durumu nedir?

5. Türkçe eğitimi alanında kadın akademisyenlerin akademik çalışmalarının türlerine göre sayısal dağlımı nasıldır?

6. Türkçe eğitimi alanında kadın akademisyenlerin makalelerinin tarandığı dizinler hangileridir?

\begin{tabular}{|c|c|}
\hline & \\
\hline alarn $D$ & d Literatur \\
\hline $\mathrm{Mal}$ & Mahallesi, Mürver Çiçeği Sokak, No:14/8 \\
\hline Kadıköy & STANBUL / TURKEY 34714 \\
\hline $\begin{array}{r}\text { e-posta: edito } \\
\text { tel: }+905057958124,+\end{array}$ & $\begin{array}{l}\text { editor@rumelide.com, } \\
\text { +90 505 7958124, +90 } 216773 \text { o } 616\end{array}$ \\
\hline
\end{tabular}




\section{Yöntem}

\section{Araștırmanın modeli}

Bu çalışma, betimsel modelde desenlenmiş nicel bir çalışmadır. Betimsel araştırmalarda amaç bir olay veya durumu olduğu gibi araştırmak ve var olan durumu belirlemektir. Betimsel çalışmalarda ele alınan olay veya durumlar ayrıntılı olarak araştırılır, daha önceki olaylar ve durumlarla ilişkisi incelenir ve "ne" oldukları betimlenmeye çalışılır (Karakaya, 2014, s.59). Türkçe eğitimi alanında kadın akademisyenlerin bibliyometrik parametreler açısından mevcut durumunun fotoğrafı çekilerek bir betimleme yapılmak istendiği için bu çalışma betimsel tarama çalışması olarak şekillendirilmiştir (Büyüköztürk, Çakmak, Akgün, Karadeniz ve Demirel, 2019).

\section{Verilerin toplanması ve analizi}

$\mathrm{Bu}$ çalışmada verilerin toplanması amacıyla doküman incelemesi tekniği kullanılmıştır. Doküman incelemesi, çalışllacak konularla ilgili yazılı ve basılı belgelerin analizini içerir (Yıldırım ve Şimşek, 2018).

Araştırmanın veri analizi tekniği, bibliyometrik analizdir. Pritchard'a (1969, s. 348) göre bibliyometri terimi, matematiksel ve istatistiksel yöntemlerin kitaplara ve diğer iletişim ortamlarına uygulanmasıdır (Akt., Al ve Coştur, 2007). Zan (2012, s.15) ise bibliyometriyi "Bilimsel çalışmaların, yazar, konu, atıf yapılan yazar, atıf yapılan kaynaklar gibi verilerin istatistiksel olarak incelenmesi ile ilgilenmekte, elde edilen istatistiksel sonuçlar doğrultusunda belirli bir disipline ait genel yapının ortaya konmasını mümkün kılmaktadır." şeklinde açıklar. Belgelerin ve yayınların belirli özelliklerini analiz etmek koşuluyla bilimsel iletişime ilişkin çeşitli bulugular elde edilmesi olarak da tanımlanmıştır (Al ve Coştur, 2007). Bu teknikle "Bilimsel iletişim dizgesindeki dokümanlar sayısal ve istatistik teknikler kullanılarak analiz edilir.” (Şeref ve Karagöz, 2019a).

Verilerin elde edilme süreci çalışmanın önemli ayaklarından biri olmuştur. Türkçe eğitimi alanındaki kadın akademisyenler ile ilgili bibliyometrik veriler 16-20 Temmuz 2020 zaman diliminde Yükseköğretim Kurulu Akademik arama adresinden alınarak Microsoft excel çalışma sayfaları oluşturulmuştur. YÖK Akademik’ten yararlanırken öncelikle "Eğitim Bilimleri ve Öğretmen Yetiştirme" bölümü seçilmiş sonrasında "Türkçe Eğitimi" anahtar kelime olarak tercih edilmiştir. Böylece Türkçe Eğitimi alanında 547 akademisyenin bulunduğu sonucuna ulaşılmıştır. Bu aşamadan sonra kadın akademisyenler bir excel belgesine işlenmiş ve 247 adet kadın akademisyenin varlığı tespit edilmiştir. Verilerin günlük değişimi çalışmayı zorlaştırmış ve sürekli güncelleme yapmayı zorunlu hale getirmiştir. Türkçe eğitimi alanındaki kadın akademisyenlerin durumunu sorgulamak için yapılan bibliyometrik analizler YÖK Akademik genel ağ sayfasındaki; "kadın akademisyenlerin çalıştıkları kurumların türleri”, "kadın akademisyenlerin unvanları", "kadın akademisyenlerin doktora ve lisansüstü tez danışmanlıkları", "kadın akademisyenlerin makalelerinin tarandığı dizinler" incelenerek gerçekleştirilmiştir.

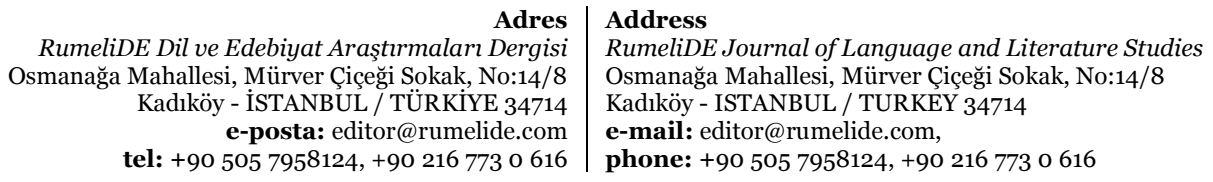


Bibliometric analysis of academic studies of women academicians in the field of Turkish language education / S. Karakuzu; M. Aras; Ö. Gedikli (pp. 691-705)

\section{Bulgular ve yorumlar}

Bu bölümde çalışma sonucunda ulaşılan veriler grafik ve tablolar kullanılarak yorumlanmıştır.

\section{Türkçe eğitimi alanında kadın akademisyenlerin sayısı}

Türkçe eğitimi alanında görev yapan kadın ve erkek akademisyenlerin sayısı ve unvanlara göre dağılımı alandaki cinsiyet ve unvan dağılım durumunu ortaya koyması açısından önemlidir. Ulaşılan bilgiler aşă̆ıda frekans ve yüzdelik olarak tablolaştırılmıştır:

Tablo 1. Türkçe eğitimi alanında kadın ve erkek akademisyenlerin unvanlarına göre dağılımı

\begin{tabular}{|c|c|c|c|c|}
\hline \multirow[t]{2}{*}{ Unvan } & \multicolumn{2}{|c|}{ Kadın Akademisyenler } & \multicolumn{2}{|c|}{ Erkek Akademisyenler } \\
\hline & $\mathrm{f}$ & $\%$ & $\mathrm{f}$ & $\%$ \\
\hline Profesör & 8 & 18,18 & 36 & 81,82 \\
\hline Doçent & 28 & 34,15 & 54 & 65,85 \\
\hline Doktor Ö Ğretim Üyesi & 71 & 47,33 & 79 & 52,67 \\
\hline Öğretim Görevlisi & 79 & 52,67 & 71 & 47,33 \\
\hline Araştırma Görevlisi & 61 & 50,41 & 60 & 49,59 \\
\hline TOPLAM & 247 & 45,16 & 300 & 54,84 \\
\hline
\end{tabular}

Tablo 1'e göre Türkçe eğitimi alanında 247 kadın, 300 erkek olmak üzere toplam 547 akademisyen bulunmaktadır. Kadın akademisyenler bu grubun \%45,16'sını oluşturmaktadır. Türkçe eğitimi alanında profesörlerin \%18,18’i (f=8), doçentlerin \%34,15’i ( $\mathrm{f}=28)$, doktor öğretim üyelerinin \%47,33’ü $(\mathrm{f}=71)$, öğretim görevlilerinin \%52,67'si $(\mathrm{f}=79)$ ve araştırma görevlilerinin \%50,41’i ( $\mathrm{f}=61)$ kadın akademisyenlerdir. Türkçe eğitimi alanında kadın akademisyenlerin erkek akademisyenlerden sayı ve yüzde olarak fazla olduğu unvanlar öğretim görevlisi ve araştırma görevlisidir. İlgili unvanlardaki sayılar incelendiğinde erkek-kadın akademisyenler arasındaki farkın düşük; öğretim görevlisi unvanında bu farkın 8, araştırma görevlisindeyse 1 olduğu görülmektedir. Yüzde olarak ele alındığındaysa öğretim görevlilerinin \%52,67’si ve araştırma görevlilerinin \%50,41’i kadındır. Bunun yanında doktor öğretim üyesi olan erkek ve kadın akademisyenlerin yüzdeleri birbirine yakın değerdedir. Ancak profesör ve doçent unvanlarında kadın akademisyenler erkek akademisyen sayısının oldukça gerisinde kalmaktadır. 


\section{Türkçe eğitimi alanında kadın akademisyenlerin unvanlarına göre dağılımı}

Aşağıda, kadın akademisyenlerin unvanlarının sayılarını ve yüzdelik dilimdeki karşılıklarını gösteren bir grafiğe yer verilmiştir:

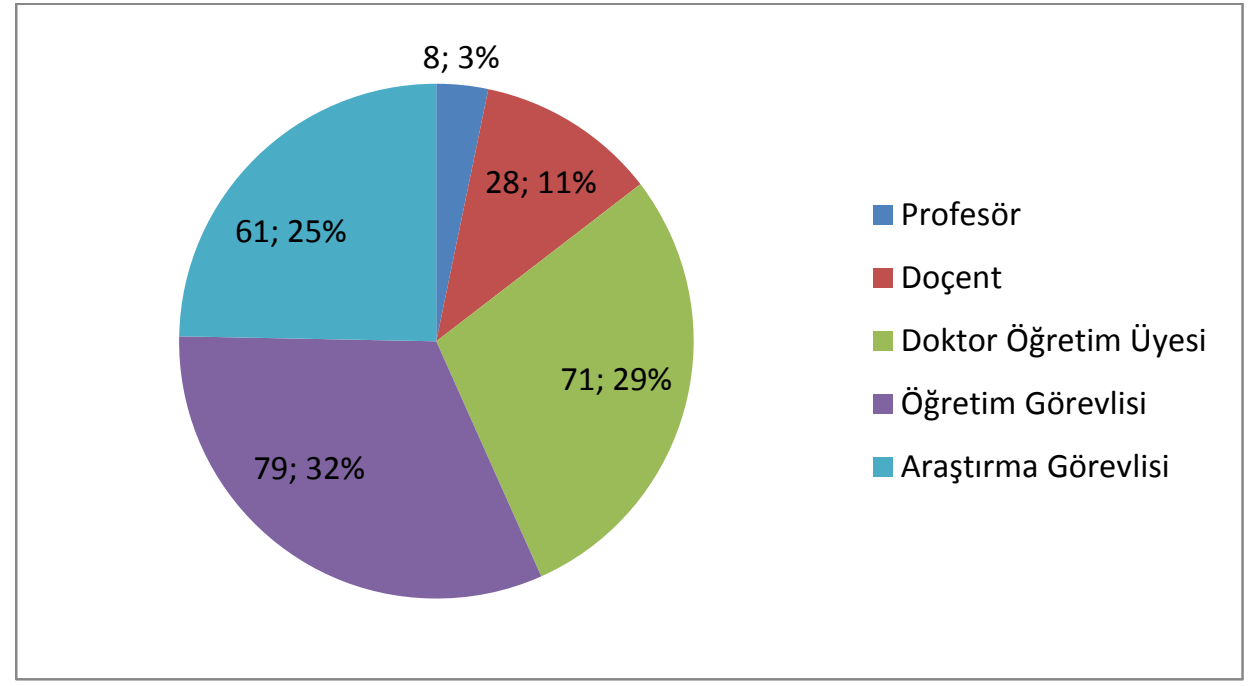

Grafik 1. Türkçe eğitimi alanında kadın akademisyenlerin unvanlarına göre durumlarının yüzdelik dağılımı

Grafik 1'e göre Türkçe eğitimi alanındaki kadın akademisyenlerin 8’i profesör (\%3), 28’i doçent(\%11), 61’i araştırma görevlisi(\%25), 71’i(\%29) doktor öğretim üyesi iken 79'uysa (\%32) öğretim görevlisidir. Bu durumda ilgili alandaki kadınların en az sahip olduğu unvan profesör ( $\mathrm{f}=8$ ) iken en fazla sahip olduğu unvanlar öğretim görevlisi $(\mathrm{f}=79)$ ve doktor öğretim üyesidir $(\mathrm{f}=71)$.

\section{Türkçe eğitimi alanında kadın akademisyenlerin çalıştıkları kurum türlerine göre dağılımı}

Kadın akademisyenlerin çalıştıkları kurum türü, incelenen bibliyometrik göstergelerden biri olarak ele alınmıştır. Aşağıda, Türkçe eğitimi alanında kadın akademisyenlerin devlet ve vakıf üniversitelerine göre dağılımını gösteren bir tabloya yer verilmiştir:

Tablo 2. Türkçe eğitimi alanında kadın akademisyenlerin çalıştıkları kurum türlerine göre dağılımı

\begin{tabular}{lllll}
\hline & Devlet & \multicolumn{3}{l}{ Vakıf } \\
\hline Unvan & $f$ & $\%$ & $f$ & - \\
\hline Profesör & 8 & 100 & - & 3,57 \\
\hline Doçent & 27 & 96,42 & 1 & 9,86 \\
\hline Dr. Öğretim Üyesi & 64 & 90,14 & 7 & 16,46 \\
\hline Öğretim Görevlisi & 66 & 85,54 & 13 & 3,28 \\
\hline Araştırma Görevlisi & 59 & 96,72 & 2 & 9,31 \\
\hline TOPLAM & 224 & 90,69 & 23 & \\
\hline
\end{tabular}

Tablo 2 incelendiğinde Türkçe eğitimi alanındaki 247 kadından 224’ünün devlet, 23’ününse vakıf üniversitelerinde görev yaptığı görülmektedir. Yüzdelik oranlar incelendiğinde, alanındaki kadın

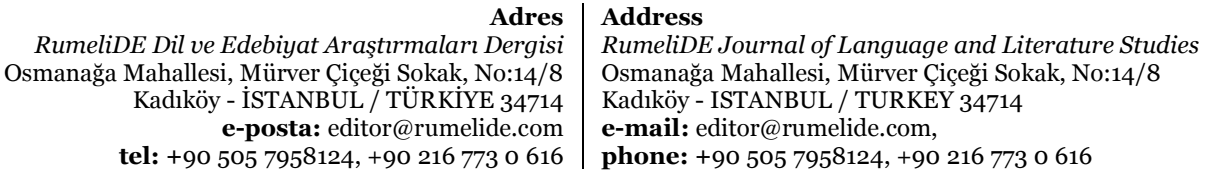


akademisyenlerin \%90,69’u devlet üniversitelerinde \%9,31’i vakıf üniversitelerinde çalışmaktadır. Alandaki profesör kadın akademisyenlerin tamamı devlet üniversitelerindedir. Doçent kadın akademisyenlerin \%96,42'si; doktor öğretim üyesi kadın akademisyenlerin \%90,14’ü; öğretim görevlisi kadın akademisyenlerin \%85,54’ü; araştırma görevlisi kadın akademisyenlerin \%96,72'si devlet üniversitelerinde çalışmaktadır. Vakıf üniversitelerinde çalışan kadın akademisyenlerden en yüksek sayıya sahip olan öğretim görevlileridir $(\mathrm{f}=13)$.

\section{Türkçe eğitimi alanında kadın akademisyenlerin yüksek lisans ve doktora tez danışmanlıklarına göre durumu}

Kadın bilim insanlarının tez danışmanlığına dair üretkenlikleri ve eğilimleri araştırmanın önemli bir parçasını oluşturmaktadır. Aşağıda Türkçe eğitimi alanında kadın akademisyenlerin unvanlarına göre danışmanlık ettikleri yüksek lisans ve doktora tez sayılarını ortaya koyan bir tablo yer almaktadır:

Tablo 3. Türkçe eğitimi alanında kadın akademisyenlerin unvanlarına göre yönettikleri tez sayıları

\begin{tabular}{lllll}
\hline & \multicolumn{2}{l}{ Yüksek Lisans Tez Danışmanlı̆̆ } & \multicolumn{2}{l}{ Doktora Tez Danışmanlı̆̆ } \\
\hline Unvan & $\mathrm{f}$ & $\%$ & $\mathrm{f}$ & $\%$ \\
\hline Profesör & 43 & 12,39 & 17 & 60,71 \\
\hline Doçent & 165 & 47,55 & 5 & 17,86 \\
\hline Dr. Öğr. Üyesi & 139 & 40,06 & 6 & 21,43 \\
\hline TOPLAM & 347 & 100 & 28 & 100 \\
\hline
\end{tabular}

Tablo 3’e göre Türkçe eğitimi alanındaki kadın akademisyenlerin danışmanlık yaptıkları yüksek lisans tezleri incelendiğinde en yüksek sayının doçentlere ait olduğu görülmektedir $(\mathrm{f}=165)$. Bu sayıyı doktor öğretim üyesi $(\mathrm{f}=139)$ ve profesör $(\mathrm{f}=43)$ unvanları takip etmektedir. Toplamda danışmanlık yapılan yüksek lisans tez sayısı ise $347^{\prime}$ dir.

Türkçe eğitimi alanındaki kadın akademisyenlerden doktora tez danışmanlığını en çok yapanlar profesörlerdir. Profesör kadın bilimciler doktora tez danışmanlığının \%60,71’ini ( $\mathrm{f}=17$ ) yapmıştır. Profesör unvanlı kadın akademisyenleri sırasıyla doktor öğretim üyesi $(\mathrm{f}=6)$ ve doçent $(\mathrm{f}=5)$ unvanlı kadın akademisyenler takip etmektedir. Doktor öğretim üyesi unvanlı kadın akademisyenlerin, doçent unvanına sahip olanlardan daha çok doktora tezi yönetmesi dikkat çeken bir durum olarak tespit edilmiştir. Genel olarak bakıldığında kadın akademisyenlerin yönettikleri toplam doktora tez sayısı 28 olarak belirlenmiştir.

Türkçe eğitimi alanında kadın bilim insanlarının lisansüstü tez danışmanlığı durumu incelendiğinde, en çok doktora tez danışmanlığı yapanlar Atatürk Üniversitesinden Prof. Dr. Muhsine BÖREKÇI $(\mathrm{f}=12)$ iken en çok yüksek lisans tez danışmanlı̆̆ yapan kadın akademisyen Dokuz Eylül Üniversitesinden Doç. Dr. Nevin AKKAYA'dır $(\mathrm{f}=27)$. Toplamda 28 doktora tezinden 12'sine danışmanlık yapan Prof. Dr. Muhsine BÖREKÇi் \%42,8'lik bir dilime sahiptir. Doç. Dr. Nevin AKKAYA ise 347 yüksek lisans tezi içinde 27 tanesine danışmanlık yaparak \%7,7'lik bir katkıda bulunmuştur.

\footnotetext{
Adres $\mid$ Address

RumeliDE Dil ve Edebiyat Araşttrmaları Dergisi $\quad$ RumeliDE Journal of Language and Literature Studies Osmanağa Mahallesi, Mürver Çiçeği Sokak, No:14/8 Osmanağa Mahallesi, Mürver Çiçeği Sokak, No:14/8

Kadıköy - İSTANBUL / TÜRKIYE 34714 Kadıköy - ISTANBUL / TURKEY 34714 e-posta: editor@rumelide.com e-mail: editor@rumelide.com,

tel: +90 505 7958124, +90 2167730616 phone: +90 505 7958124, +90 2167730616
} 


\section{Türkçe eğitimi alanında kadın akademisyenlerin akademik çalışmalarının türlerine göre sayısal dağılımı}

Türkçe eğitimi alanındaki kadın bilim insanlarının yayımladığı kitap-kitap bölümü, makale ve bildiriler araştırılarak üretken yazarlık durumları tespit edilmiştir. İlgili veriler aşağıda unvanlar bazında gösterilmiştir:

Tablo 4. Türkçe eğitimi alanında kadın akademisyenlerin unvanlarına göre yayın sayıları

\begin{tabular}{llll}
\hline Unvan & Kitap-Kitap Bölümü & Makale & Bildiri \\
\hline Profesör & 72 & 217 & 218 \\
\hline Doçent & 265 & 770 & 714 \\
\hline Doktor Öğretim Üyesi & 261 & 767 & 855 \\
\hline Öğretim Görevlisi & 162 & 156 & 169 \\
\hline Araştırma Görevlisi & 69 & 249 & 397 \\
\hline TOPLAM & 829 & 2.159 & 2.353 \\
\hline
\end{tabular}

Tablo 4'e göre Türkçe eğitimi alanındaki kadın akademisyenlerin en fazla yayın yaptıkları tür bildiridir $(\mathrm{f}=2.353)$. Bunu makale ( $\mathrm{f}=2.159)$ ve kitap-kitap bölümü $(\mathrm{f}=829)$ takip etmektedir. Alandaki kadın akademisyenlerin ortalama kitap-kitap bölümü yayın sayısı 3,35; ortalama makale yayın sayısı 8,74 ve ortalama bildiri yayın sayısı ise 9,52'dir. Unvanlarına göre incelendiğinde profesörlerin 63,37; doçentlerin 62,46; doktor öğretim üyelerinin 26,52; öğretim görevlilerinin 6,16 ve araştırma görevlilerinin 11,72 ortalama yayın yaptığı sonucuna ulaşılmıştır.

Doçent kadın bilimciler 265'le en çok kitap-kitap bölümü, 770'le en çok bildiriye sahip kişiler olmuştur. Doktor öğretim üyesi olan kadın akademisyenler de cüzi bir farkla doçentleri takip etmektedir. Yayımlanan en çok bildiri sayısında ise 855 ile doktor öğretim üyeleri, alana en büyük katkıyı sağlayan unvana sahip kadın akademisyenler olmuştur.

Türkçe eğitimi alanında en çok kitap-kitap bölümü yayını bulunan İstanbul ÜniversitesiCerrahpaşadan Doç. Dr. Fatma Bölükbaş'tır $(\mathrm{f}=27)$. Bununla birlikte Dokuz Eylül Üniversitesinden Doç. Dr. Nevin Akkaya alanda en çok makale yayını $(\mathrm{f}=5 \mathrm{O})$ ile en çok bildirisi $(\mathrm{f}=72)$ bulunan kadın akademisyen olarak karşımıza çımmaktadır.

Genel olarak bakıldığında alanda en çok bilimsel yayını bulunan kadın akademisyen Dokuz Eylül Üniversitesinden Doç. Dr. Nevin AKKAYA'dır ( $\mathrm{f}=133$ ). Alanda herhangi bir bilimsel yayını bulunmayan kadın akademisyen sayısıysa 32'dir. Bu akademisyenlerin 22'si devlet üniversitelerinde ve 10’u vakıf üniversitelerinde görev yapmaktadır. Bilimsel yayını bulunmayan kadın akademisyenlerin unvanları; öğretim görevlisi ( $\mathrm{f}=25)$, araştırma görevlisi $(\mathrm{f}=4)$ ve doktor öğretim üyesidir $(\mathrm{f}=3)$.

\section{Türkçe eğitimi alanında kadın akademisyenlerin makalelerinin tarandığı dizinler}

Bilim insanlarının akademik alanda yayımladıkları makalelerin tarandı̆̆ı dizinler bilime katkının değerlendirilmesi açısından önemli bir değişken olarak gösterilebilir. Bu sebeple Türkçe eğitimi alanında görev yapan kadın bilimcilerin makalelerinin tarandı̆̆ı dizinler araştırılmış ve bazı veriler elde edilmiştir. İlgili veriler aşă̆ıda Türkçe eğitimi alanında kadın akademisyenlerin unvan durumlarına göre tablolaştırılmıştır:

\begin{tabular}{|c|c|}
\hline & \\
\hline aları $D$ & d Literatur \\
\hline $\mathrm{Mal}$ & Mahallesi, Mürver Çiçeği Sokak, No:14/8 \\
\hline Kadıköy & STANBUL / TURKEY 34714 \\
\hline $\begin{array}{r}\text { e-posta: edito } \\
\text { tel: }+905057958124,+\end{array}$ & $\begin{array}{l}\text { editor@rumelide.com, } \\
\text { +90 505 7958124, +90 } 216773 \text { o } 616\end{array}$ \\
\hline
\end{tabular}


700 / RumeliDE Journal of Language and Literature Studies 2021.22 (March)

Bibliometric analysis of academic studies of women academicians in the field of Turkish language education / S. Karakuzu; M. Aras; Ö. Gedikli (pp. 691-705)

Tablo 5. Türkçe eğitimi alanında kadın akademisyenlerin makalelerinin tarandığı dizinler

\begin{tabular}{lllll}
\hline Unvan & SSCI, AHCI, ESCI & ERIC, HW Wilson & TR Dizin & Diğer Endeksler \\
\hline Profesör & 27 & 10 & 73 & 107 \\
\hline Doçent & 40 & 65 & 281 & 384 \\
\hline Doktor Öğretim Üyesi & 33 & 80 & 337 & 317 \\
\hline Öğretim Görevlisi & 2 & 6 & 43 & 105 \\
\hline Arş. Görevlisi & 15 & 12 & 89 & 133 \\
\hline TOPLAM & 117 & 173 & 823 & 1046 \\
\hline
\end{tabular}

Tablo 5'e göre Türkçe eğitimi alanındaki kadın akademisyenlerin makalelerinin diğer endekslerde yoğunlaştığı görülmektedir ( $\mathrm{f}=1046)$. Bunu sırasıyla TR dizin ( $\mathrm{f}=823)$; ERIC, HW Wilson ( $\mathrm{f}=173$ ) ve SSCI, AHCI, ESCI ( $\mathrm{f}=117)$ takip etmektedir. Alandaki kadın akademisyenler unvanlarına göre incelendiğindeyse makalelerinin dizinlendiği SSCI, AHCI, ESCI endekslerinde doçent $(\mathrm{f}=40)$; ERIC, HW Wilson endekslerinde doktor öğretim üyesi $(\mathrm{f}=80$ ); TR Dizinde Doktor Öğretim Üyesi Üyesi $(\mathrm{f}=337)$; diğer endekslerde ise $\operatorname{doçent}(\mathrm{f}=384)$ en fazla makaleye sahiptir. Bütün endekslerde yayımlanan makale sayısı 2.159'dur.

Türkçe eğitimi alanında tabloda belirtilen dizinlerde en çok makaleye Dokuz Eylül Üniversitesinden Doç. Dr. Nevin Akkaya $(\mathrm{f}=50)$ sahiptir ve makaleleri en fazla diğer endekslerde dizinlenmektedir $(\mathrm{f}=38)$.

\section{Sonuç, tartışma ve öneriler}

Bibliyometrik analiz, bilimsel çalışmaları ülke, kurum, alan yazın, dergi, bilim insanı vb. açısından incelemeye imkân sağlayan bir teknik olarak tanımlanabilir. Bibliyometrik analiz, doküman incelemesi ve içerik analizinden farklı olarak bir alandaki çalışma dinamiklerini ve eğilimlerini ortaya koyması açısından işlevseldir (Şeref ve Karagöz, 2019b). Bibliyometrik çalışmanın bu işlevsel yönünden faydalanarak ortaya konan bu çalışma, Türkiye'de Türkçe Eğitimi alanındaki kadın akademisyenlerin üretken bilim insanı analizini sunmaktadır. Araştırma kapsamında, Türkçe eğitimi alanında görev yapan kadın akademisyenlerin sayılarına, unvanlarına, çalıştıkları üniversitelere, doktora ve lisanasüstü tez danışmanlıklarına ve yayın türlerine ulaşılmış, bu verilerden yola çıkılarak Türkçe eğitimi alanında kadın akademisyenlerin yayın üretkenliği ortaya konmuştur. Çalışmada şu sonuçlara varılmıştır:

1. Türkçe eğitimi alanında 247 kadın, 300 erkek olmak üzere toplam 547 akademisyen bulunmaktadır. $\mathrm{Bu}$ verilerden yola çıkıldığında kadın akademisyenlerin bu grubun \%45,16'sını oluşturduğu görülmektedir. Sonuç olarak ilgili alandaki kadın akademisyenlerin varlıklarının azımsanamayacak durumda olduğu açıkça görülmektedir. Bununla birlikte yeni bir disiplin alanı olan Türkçe eğitiminde çağa uygun olarak kadın ve erkek akademisyenler arasında sayısal anlamda önemli bir farklılığın olmaması bu çalışmanın önemli bulgularından bir diğeridir.

$\mathrm{Bu}$ çalışma, ülkemizdeki kadın akademisyenlerin erkek akademisyenlerle nicelik olarak birbirine yaklaşması sonucunda akademik alanlarda hangi cinsiyetteki akademisyenlerin ağır bastığına yönelik araştırmalardan biri olarak görülebilir. Elde edilen bibliyometrik göstergeler sonucunda Türkçe eğitimi alanında cinsiyet açısından yatay bir ayrışmanın olmadığı tespit edilmiştir. Niceliksel olarak her geçen gün artan kadın akademisyenlerin niteliksel gelişmesini ortaya koymayı amaçlayan bu

\footnotetext{
\begin{tabular}{r|l} 
Adres & Address \\
RumeliDE Dil ve Edebiyat Araşttrmaları Dergisi & RumeliDE Journal of Language and Literature Studies
\end{tabular} Osmanağa Mahallesi, Mürver Çiçeği Sokak, No:14/8 Osmanağa Mahallesi, Mürver Çiçeği Sokak, No:14/8 Kadıköy - İSTANBUL / TÜRKIYE 34714 Kadıköy - ISTANBUL / TURKEY 34714 e-posta: editor@rumelide.com e-mail: editor@rumelide.com, tel: +90 505 7958124, +90 2167730616 phone: +90 505 7958124, +90 2167730616
} 
çalışma kadın akademisyenlerin üretkenlik durumlarını farklı değişkenler nezdinde inceleyerek önemli sonuçlar elde etmiştir.

2. Kadın akademisyenlerinin mesleki yükselmelerini gösteren değişkenlerden biri unvanlardaki dağılımlarıdır. Bu çalışma bağlamında kadın akademisyenlerin en yüksek sayıda öğretim görevlisi unvanına ( $f=79$ ), en az olarak da profesör unvanına $(f=8)$ sahip oldukları saptanmıştır. Kadın ve erkek akademisyenlerin unvanları nicelik açısından karşılaştırıldığında doçentlikte ciddi bir fark görünmezken profesörlükte fark, kadınların aleyhine önemli sayıda artmaktadır. Bu büyük fark; kadın akademisyenlere yüklenen araştırmacı, eğitimci, meslektaş gibi rollerin yanında görünmeyen emek olarak değerlendirilen eş ve anne olmanın getirdiği rol çatışmaları ile açılanabilir. Aytaç, M., Aytaç, S., Fırat, Bayram ve Keser (2001) çalışmalarında, evin temel yükümlülüklerini üstlenen, aile ve kariyer rolleri arasında kalan kadınların bilimsel üretkenliklerinin azaldığını ortaya koymuştur. Bunun yanında toplumsal cinsiyet eşitsizliğinin olması da kadın profesör ve doçent akademisyen sayısının azlığına sebep olarak gösterilebilir.

3. Çalışmada üzerinde durulan konulardan biri kadın akademisyenlerin devlet ve vakıf üniversitelerindeki unvan bakımından dağılımlarıdır. Bu noktada dikkat çeken verilerden biri, Türkçe eğitimi alanında, vakıf üniversitelerinde çalışan kadın profesörün olmamasıdır. Bununla birlikte, vakıf üniversitelerinde diğer unvanlardaki kadın akademisyen sayılarının da 247 kişi içinden sadece 23 olması dikkat çeken diğer bir veridir. Diğer bir deyişle kadın akademisyenlerin yalnızca \%9,3’ünün vakıf üniversitelerinde çalıştı̆̆ tespit edilmiştir.

4. Cinsiyet açısından doktor öğretim üyesi, öğretim görevlisi ve araştırma görevlisi unvanları arasında çok fazla fark olmamakla birlikte öğretim görevlisi ve doktor öğretim üyesi olarak görev alan kadınların erkeklerden fazla olduğu da görülmektedir. Bu da kadın akademisyenler için oldukça önemli bir gelişme olarak görülebilir. Türkçe eğitimi alanı yeni bir bilimsel disiplin olmasına rağmen kadın ve erkek akademisyenler karşılaştırıldıklarında aralarında büyük farkların olmaması akademide cinsiyet eşitliğinin varlığı açısından önemli bir bulgu olarak değerlendirilebilir.

Unvanlara göre elde edilen verilerde, doktor öğretim üyesi sayısının \%29'luk bir oranda olması, gelecekteki doçent kadın akademisyenlerin varlığına işaret olarak yorumlanabilir. Bunun yanında \%25'lik bir paya sahip olan araştırma görevlileri de kadın akdemisyenlerin geleceğine dair umut vaat etmektedir.

5. Türkçe eğitimi alanındaki kadın bilimcilerin, lisansüstünde tez danışmanlı̆̆ yapmaya yönelik eğilimlerini ortaya koyan veriler yüksek lisans ve doktora olarak iki kısımda ele alınmıştır. Bu bağlamda yüksek lisans tez danışmanlığı yapan kadın bilimcilerin \%47,55'lik dilimini doçent, \%40,06'llk dilimini ise doktor öğretim üyesi unvanına sahip akademisyenlerin oluşturduğu belirlenmiştir. Yüksek lisans tez danışmanlığında en az paya sahip kişilerinse \%12,39'la profesör unvanına sahip akademisyenlerin olduğu görülmektedir. Profesör kadın bilimcilerin yüksek lisansta yüzdelik olarak az bir paya sahip olması, doktora tez danışmanlığına yönelmeleri ve sayıca diğer unvanlardan az olmalarıyla açılanabilir. Diğer yandan doktora tez danışmanlık eğilimlerinde kadın profesörlerin toplamda 28 doktora tezinden 17 'sini üstlendiklerine, yüzde olaraksa \%60'lık bir orana sahip olduklarına dikkat çekilmelidir. Sonuç olarak ilgili alandaki kadın profesörler, yüksek lisans tezlerinden daha çok doktora tezlerine danışmanlık etmektedir.

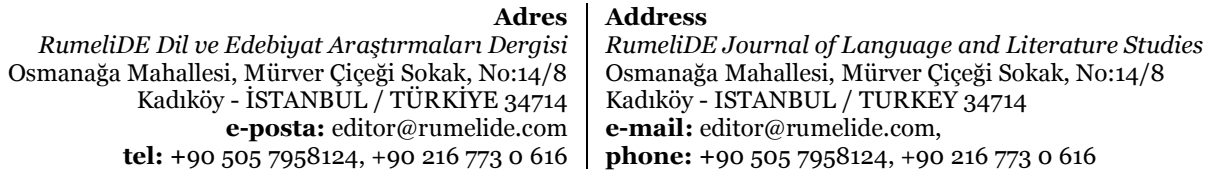

RumeliDE Dil ve Edebiyat Araşttrmaları Dergisi -posta: editor@rumelide.com tel: +90 505 7958124, +90 2167730616
Address

Osmanağa $\mathrm{Mat}$

e-mail: editor@rumelide.com

phone: +90 5057958124 , +90 2167730616 
Bibliometric analysis of academic studies of women academicians in the field of Turkish language education / S. Karakuzu; M. Aras; Ö. Gedikli (pp. 691-705)

6. Türkçe eğitimi alanındaki kadın bilim insanlarının akademik çalışmalarının türlerine göre incelenmesi, çalışmanın önemli bir başka ayağıdır. Bu bağlamda, kadın akademisyenlerin kitap-kitap bölümleri, makale ve bildirileri unvanları açısından ortaya konulmuştur.

Edinilen veriler ışığında, toplamda yayımlanan 829 kitap-kitap bölümü çalışması arasında 265’le doçentlerin ilk sırada olduğu görülmektedir. Bu sayııı hemen ardından 261'le doktor öğretim üyesi bilim insanlarının takip ettiği görülmektedir. Öğretim görevlileri, bu çalışma türünde alana 162 kitapkitap bölümü ile katkı sağlamıştır.

En az kitap-kitap bölümüne sahip unvanların ise 69'la araştırma görevlileri ve 72'yle profesörler olması dikkat çekici bir sonuç olarak karşımıza çıkmaktadır. Burada profesörlerin ( $\mathrm{f}=8$ ) sayılarının araştırma görevlilerinin $(\mathrm{f}=61)$ sayısından oldukça az olduğuna dikkat edilmelidir. Bunun yanında akademik yükselişteki ihtiyaç durumları da dikkate alındığında, araştırma görevlilerinin üretkenlik için olumlu bir şekilde yönlendirildiği söylenebilir.

Akademik çalışmaların türlerinden bir diğeri olan makaleler incelendiğinde, toplam 2.159 makale içinden yine doçent $(\mathrm{f}=770)$ ve doktor öğretim üyesi $(\mathrm{f}=767)$ unvanına sahip akademisyenlerin en yüksek sayıda esere sahip olduğu görülmektedir. Bu sayıy ciddi bir fark olsa da 249 makaleyle araştırma görevlisi kadın bilim insanları takip etmiştir.

Kadın akademisyenlerin bildiri üretkenlik sayıları incelendiğinde doçent ve doktor öğretim üyelerinin yine ilk sıralarda yer aldığı görülmektedir. Ancak diğerlerin aksine bu yayın türünde, doktor öğretim üyelerinin $(\mathrm{f}=855)$ doçentlerden $(\mathrm{f}=714)$ önemli bir farkla önde olduğu belirlenmiştir. Bildiri türünde ilgili unvanları takip eden grup 397'yle araştırma görevlileridir. Profesörler 218 bildiri sunarken öğretim görevlileri 169’la en az sayıda çalışma ortaya koyan grup olarak belirlenmiştir.

Türkçe eğitimi alanındaki kadın bilim insanlarının çeşitli sempozyum ve kongrelere katılıp 2.353 bildiri sunarak geniş bir topluluğa hitap ettikleri görülmektedir. Bunun yanında kadın akademisyenlerin toplamda 2.159 makale yayımlaması, ilgili alana sundukları büyük katkının göstergelerinden bir diğeridir. Akademik çalışmaların önemli bir ayağı olan kitap-kitap bölümü yazma noktasında toplamda 829 eser verilmesi bilimsel üretkenlik açısından önemli bir başka gelişmedir. En çok kitap-kitap bölümü yazanların doçent, en çok bildiri sunanların ise doktor öğretim üyesi unvanına sahip olduğu belirlenmiştir.

7. Türkçe akademik alanındaki kadın akdemisyenlerin makalelerinin tarandığı dizinler için SSSCI, AHCI, ESCI; ERIC, HW WILSON, TR Dizin ve Diğer Endeksler ölçüt olarak alınmıştır. Bu bağlamda, makalelerin en çok tarandığ 1 dizinlerin Diğer Endeksler $(f=1.046)$ ve TR Dizin $(f=823)$ olduğu görülmektedir. ERIC, HW WILLSON dizinlerine bakıldığında ulaşılan sayı 173’ü bulmaktadır. En az yayının olduğu dizinin toplamda 117 ile SSCI, AHCI, ESCI olduğu görülmüştür. Sonuç olarak, \%48,4 oranıyla makalelerin ağırlıklı olarak diğer endekslerde yayımlandığı sonucuna ulaşılmıştır.

$\mathrm{Bu}$ çalışmanın sonunda araştırmacılara şu önerilerde bulunulabilir:

- Çalışmada Türkçe eğitimindeki kadın akademisyenler üzerine çalışılmıştır. Benzer çalışmalar farklı akademik alanlarda gerçekleştirilebileceği gibi aynı alandaki erkek akademisyenlerin üretken yazar analizi de yapılabilir.

- Bu çalışmada Türkçe eğitiminde kadın akademisyenlerin bilimsel çalışmaları niceliksel olarak incelenmiştir. Kadın akademisyenlerin bilimsel çalışmalarının niteliksel özellikleri ayrı bir çalışma olarak ele alınabilir.

\begin{tabular}{r|l} 
Adres & $\begin{array}{l}\text { Address } \\
\text { RumeliDE Dil ve Edebiyat Araştırmaları Dergisi } \\
\text { RumeliDE Journal of Language and Literature Studies }\end{array}$ \\
Osmanağa Mahallesi, Mürver Çiçeği Sokak, No:14/8 & Osmanağa Mahallesi, Mürver Çiç̧̧i Sokak, No:14/8 \\
Kadıköy - İSTANBUL / TÜRKIYY 34714 & Kadıköy - ISTANBUL / TURKEY 34714 \\
e-posta: editor@rumelide.com & e-mail: editor@rumelide.com, \\
phone: +90 505 7958124, +90 2167730616
\end{tabular}


- Kadın akademisyenlerin çalışma yaptıkları konu alanları ve kullandıkları anahtar kelimeler üzerinde de yeni çalışmalar yapılarak hangi konulara eğilimlerinin olduğu tespit edilebilir.

- Türkçe eğitiminde profesör unvanına sahip 8 kadın akademisyenle çeşitli görüşmeler yapılarak deneyimlerini yansıtan, alandaki diğer 239 akademisyeni teşvik edici ve yönlendirici bir çalışma ortaya konulabilir. Benzeri bir çalışma Türkçe eğitiminde en üretken kadın yazarlarla da yapılabilir.

\section{Kaynakça}

Adak, N. (2018). Akademide kadınlar: Yükseköğrenime giriş ve kariyerde ilerleme. Akdeniz Kadın Çalışmaları ve Toplumsal Cinsiyet Dergisi, I (1) 23-38.

$\mathrm{Al}$, U. ve Coştur, R. (2007). Türk Psikoloji Dergisi'nin bibliyometrik profili. Türk Kütüphaneciliği, 21(2), 142-163.

Altaş, A. (2017). Türkçeye tercüme edilen gastronomi kitaplarının bibliyometrik analizi. Kırklareli Üniversitesi Sosyal Bilimler Dergisi, 1, 104-117.

Altınoluk Düztaş, D. (2018). Kadın olmak mı, akademisyen olmak mı? : İşte bütün mesele bu. Fe Dergi, 2018(1), 58-66.

Karakaya, İ. (2014). Bilimsel araştırma yöntemleri. A. Tanrı̈̈̆en (Ed.). Ankara: Anı.

Aytaç, M., Aytaç, S., Furat, Z., Bayram, N. ve Keser, A. (2001). Akademisyenlerin çalışma yaşamı ve kariyer sorunları. Bursa: Uludağ Üniversitesi Araştırma Fonu İşletme Müdürlüğü.

Bakioğlu, A. ve Ülker, N. (2018). Career barriers faced by Turkish women academics: Support for what? Yükseköğretim Dergisi, 2018(3), 313-321.

Başarır, F., ve Sarı, M. (2015). Kadın akademisyenlerin kadın akademisyen olmaya ilişkin algılarının metaforlar yoluyla incelenmesi. Yükseköğretim ve Bilim Dergisi, 2015(1), 41-51.

Bayramoğlu, G. (2018). İş/aile sınırı teorisi bağlamında kadın akademisyenlerin iş/yaşam dengesinin sağlanmasına yönelik bir araştırma. Elektronik Sosyal Bilimler Dergisi (Elektronik), 2018(68), 1722-1744.

Büyüköztürk, Ş., Kılıç Çakmak, E., Akgün, Ö. E., Karadeniz, Ş. ve Demirel, F. (2019). Bilimsel araştırma yöntemleri. Ankara: Pegem.

Çakır, İ. ve Arslan, R. (2018). Türkiye'deki üniversitelerde kadın akademisyenlerin karşılaştıkları sorunlar ve Bartın Üniversitesinde çalışan kadın akademisyenler üzerine bir araștırma. Bartın Üniversitesi İktisadi ve İdari Bilimler Fakültesi Dergisi, 9 (18) , 265-280.

Çiçekli, A. (2019). Akademide toplumsal cinsiyet: Sosyoloji bölümü örneklemi. Karadeniz Uluslararası Bilimsel Dergi, (42) , 51-75.

Demir, S. (2018). Akademide kadın: Farklı disiplinlerden kadınların akademideki yeri ve aile yaşamlarıyla etkileşimi. Marmara Üniversitesi Siyasal Bilimler Dergisi, 2018(1), 187-209.

Dikmen, N. ve Maden, D. (2012). Kadın akademisyenlerin görünmeyen emeği üzerine bir araştırma: Ordu Üniversitesi örneği. İstanbul Ticaret Üniversitesi Sosyal Bilimler Dergisi, 2012(21), 257287.

Ehtiyar, V. R. , Solmaz, C., ve Üst Can, Ç. (2019). "Kadın akademisyen" olmak: Turizm alanındaki kadın akademisyenlere yönelik bir metafor çalışması. Seyahat ve Otel İşletmeciliği Dergisi,16 (2), 296-318.

Ercan Demirel, E. ve Erdiren Çelebi, M. (2019). Therelation ship of burn out with work a holism mediated by work-family life conflict: A study on female academicians. Journal of Language and Linguistic Studies, 2019(4),1300-1316.

Gönenç, İ. M., Akgün, Ş. A., Özvarış, B. Ş., ve Tunç, T. E. (2013). An analysis of the relationship between academic career and sex at Hacettepe University. Education \& Science/Egitim ve Bilim, 38(170).

\begin{tabular}{|c|c|}
\hline Adres & Address \\
\hline DE Dil ve Edebiyat Arc & RumeliDE Journal of Language and Literature Studies \\
\hline No & okak, No:14/8 \\
\hline $\begin{array}{r}\text { Kadıköy - İSTANBUL / TÜRKIYE } 34714 \\
\text { e-posta: editor@rumelide.com } \\
\text { tel: +90 } 5057958124,+902167730616\end{array}$ & $\begin{array}{l}\text { Kadıköy - ISTANBUL / TURKEY } 34714 \\
\text { e-mail: editor@rumelide.com, } \\
\text { phone: +90 } 5057958124,+90216773 \text { o } 616\end{array}$ \\
\hline
\end{tabular}


Bibliometric analysis of academic studies of women academicians in the field of Turkish language education / S. Karakuzu; M. Aras; Ö. Gedikli (pp. 691-705)

Güzel, A. (2010). Türkçe eğitimi bölümlerinde kurulması gerekli görülen ana bilim dalları. TÜBAR: 27Bahar.

Karagöz, B. ve Şeref, İ. (2019a). Okuma alanındaki araştırmaların bibliyometrik özellikler açısından incelenmesi . Ana Dili Ĕ̈itimi Dergisi, 7 (3) , 781-799 . DOI: 10.16916/aded.581630

Karagöz, B. ve Şeref, İ. (2019b). Yunus Emre ile ilgili araştırmaların bibliyometrik analizi. Akdeniz Eğitim Araştırmaları Dergisi, 13(27), 123-141. doi: 10.29329/mjer.2019.185.6

Küçükaslan, Ö., Başağaç, G. R. T., ve Ünsal, A. (2017). Türk veteriner hekimliği öğretiminde ilk kadın akademisyenler. Ankara Üniversitesi Veteriner Fakültesi Dergisi, 2017(4), 255-260.

Nergiz, G.H. (2019). Turizmde kadın akademisyenler. Anatolia: Turizm Araştırmaları Dergisi, 30(2), 89-99.

Özdemirkıran, M. ve Öner, S. (2017). Türkiye'de kadın uluslararası ilişkiler akademisyenlerinin profili : Marmara Bölgesi. Fe Dergi, 2017(1), 92-112.

Özkanlı, Ö. (2007). Türkiye'de kadın akademisyenlerin durumu. Eğitim ve Bilim, 20o7(144), 59-70.

Özkanlı, Ö. (2010). Türkiye'de üniversitelerde üst düzey kadın yöneticilerin karşılaştıkları kültürel ve yapısal engeller. Mülkiye Dergisi, 2010 (268), 265-279.

Öztan, E. ve Doğan, S. N. (2015). Akademinin cinsiyeti: Yıldız Teknik Üniversitesi örneği üzerinden üniversite ve toplumsal cinsiyet. Çalışma ve Toplum, 2015(46), 191-222.

Öztürk, U. (2017). Akademideki topuk sesleri: Cam tavan perspektifinde göller bölgesi üniversitelerinin betimsel analizi. PESA Uluslararası Sosyal Araştırmalar Dergisi, 3 (4), 202213 .

Sart, G., Sezgin, F. H. ve Demir, N. (2018). Mobbingin mesleki tükenmişlik algısı üzerine etkileri: kadın akademisyenler örneği. Beykoz Akademi Dergisi, 2018(1), 118-135.

Suğur, S. ve Cangöz, İ. (2016). Üniversite yönetiminde kadınların eksik temsili üzerinde toplumsal cinsiyet ilişkilerinin rolü. Amme İdaresi Dergisi, 2016(3), 89-115.

Şentürk, B. (2016). Çokuz ama yokuz: Türkiye'deki akademisyen kadınlar üzerine bir analiz. ViraVerita E-Dergi, 2015 (2) , 1-22.

Şentürk, İ. (2012). Üniversitede kadın olmak: Akademik örgütte toplumsal cinsiyet sorunu: Nitel bir çalışma. Kadın/Woman 2000 - Kadın Araştırmaları Dergisi, 2012(2), 13-46.

Şeref, İ. ve Karagöz, B. (2019). Scopus veri tabanına dayalı bibliyometrik değerlendirme: Mevlâna Celâleddin Rumî üzerine yapılan araştırmalar. RumeliDE Dil ve Edebiyat Araştırmaları Dergisi , (14) , 298-313 . DOI: 10.29000/rumelide.541024.

Taylor Machado, M. de L., ve Özkanlı, Ö. (2013). Gender and academic careers in Portuguese and Turkish higher education institutions. Eğitim ve Bilim, 2013(169), 346-356.

Tepe, F. F. (2018). 200o'lerde Türkiye'de kadın akademisyenler: rol çatışması mı veya rol genişlemesi mi? Yükseköğretim ve Bilim Dergisi, 2018(2),271-279.

URL 1: http://www.tuik.gov.tr/Start.do adresinden 04.12.2020 tarihinde erişilmiştir.

Ünnü Ayyıldız, N. A., Baybars, M., ve Kesken, J. (2014). Türkiye'de kadınların üniversiteler bağlamında yetki ve karar verme mekanizmalarına katılımı. Dumlupınar Üniversitesi Sosyal Bilimler Dergisi, 2014(42), 121-134.

Yalçın, H. ve Demirekin, M. (2013). Lisans eğitimi alan öğrencilerin, kadın akademisyenlerin çalışma yaşamındaki durumlarına yönelik algıları. Yükseköğretim ve Bilim Dergisi, 2013(2), 166-172.

Yalçınkaya, Y. ve Özkan, H. H. (2012). 2000-2011 ylları arasında eğitim fakülteleri dergilerinde yayımlanan matematik öğretimi alternatif yöntemleri ile ilgili makalelerin içerik analizi. Süleyman Demirel Üniversitesi Sosyal Bilimler Enstitüsü Dergisi, 2(16).

Yenilmez, M. İ. (2016). Women in academia in Turkey: Challenges and opportunities. Yönetim Bilimleri Dergisi, 2016(28), 289-311.

\begin{tabular}{|c|c|}
\hline & \\
\hline alarn $D$ & d Literatur \\
\hline $\mathrm{Mal}$ & Mahallesi, Mürver Çiçeği Sokak, No:14/8 \\
\hline Kadıköy & STANBUL / TURKEY 34714 \\
\hline $\begin{array}{r}\text { e-posta: edito } \\
\text { tel: }+905057958124,+\end{array}$ & $\begin{array}{l}\text { editor@rumelide.com, } \\
\text { +90 505 7958124, +90 } 216773 \text { o } 616\end{array}$ \\
\hline
\end{tabular}


Yıldırım, A. ve Şimşek, H. (2018). Sosyal bilimlerde nitel araştırma yöntemleri. Ankara:Seçkin .

Yıldız, S. (2018). Türkiye'de kadın akademisyen olmak. Yükseköğretim ve Bilim Dergisi, 2018(1), 2940.

Yılmaz, E. ve Özdemir, G. (2012). Türkiye'de kadın akademisyen ve araştırmacıların karşılaştıkları sorunlar ve tarıma bakış açıları. Tekirdağ Ziraat Fakültesi Dergisi, 9 (2), 50-56.

Zan, U. B. (2012). Türkiye'de Bilim Dallarında Karşılaştırmah Bibliyometrik Analiz Çalş̧ması. Yayımlanmamış Doktora Tezi, Ankara Üniversitesi, Ankara. 